\title{
Role of Land Asset Officers on The Installation of Certificate Liability Rights Who Died
}

\section{Dian Melina *)}

*) PPAT of Tegal Regency, Email: melinadian@ymail.com

Abstract. Mortgage is a security right that is imposed on land rights as referred to in Act No. 5 of 1960 concerning Basic Agrarian Principles, along with other objects which are an integral part of the land, for the settlement of certain debts, which provide positions that give priority to certain creditors over other creditors. There are still those who use the name of a certificate of ownership right who has passed away for the installation of mortgage. The purpose of this research is to find out the role of land deed maker officials in the installation of mortgages with the name of a certificate of ownership that has passed away, which is carried out by the process of Inheritance to Inheritance Based on Justice. Problems is the process of inheriting inheritance to an inheritance based on justice, and how to overcome the problem of the role of land deed-making officials in the installation of mortgage rights under the name of a certificate of ownership that has passed away, which is carried out by the process of Inheritance to Justice-based Inheritance. This study uses a normative juridical approach, in data collection it is more emphasized on the decomposition and interpretation of data related to legal principles. The results are; The Role of Land Deed Making Officials in the Installation of Mortgage Rights with the Name of Ownership Certificates that have Died, which is carried out by the Inheritance process to Inheritance Based on Justice.

Keywords: Land Deed Maker Officials; Mortgage Rights; Certificate; Inheritance.

\section{INTRODUCTION}

The national development that we are currently carrying out is a form of mandate for the welfare of the people. In carrying out development activities, the funding factor plays an important role. We can get these funds from various sources, including by way of credit or credit from banks.

Banks in providing credit to entrepreneurs/customers must have confidence in the ability and ability of the debtor to pay off their debts as agreed, because the credit given by the bank contains risks, so that in its implementation the bank must pay attention to the principles of sound credit. ${ }^{1}$

\footnotetext{
${ }^{1}$ Chusna, Amalia., \& Hafidz, Jawade. (2019). The Role of the Notary in the Credit Agreement with Mortgage Guarantee (Case Study in the Bank Tabungan Negara (Persero) Tbk). JURNAL
} 
To reduce this risk, the guarantee of credit extension in the sense of confidence in the ability and ability of the debtor to pay off his debt is an important factor that must be agreed by the bank. To obtain this confidence, before extending credit, a bank must conduct a careful study of the character, ability, capital and collateral as well as business prospects, known as $5 \mathrm{C}$ in banking. ${ }^{2}$

\section{METHODS}

This study uses a normative juridical approach, in data collection it is more emphasized on the decomposition and interpretation of data related to legal principles and descriptive analytical approach. Descriptive analysis is research that describes an analysis of the existing findings. ${ }^{3}$ Descriptive analysis approach in this study, is the approach in terms of legislation and legal norms in accordance with the existing problems.

\section{RESULTS AND DISCUSSION}

\subsection{The Role of Land Deed Making Officials in the Installation of Mortgage Rights with the Name of Ownership Certificate that has died, which is carried out by the process of Inheritance to Justice-Based Inheritance}

\section{a. Inheritance Process}

The process of installing a mortgage with a certificate of ownership rights that has passed away must go through the inheritance stage. Inheritance means a series of processes for transferring land ${ }^{4}$ ownership from the name of the deceased certificate or the heir to the name of all heirs, from the stage of collecting heir data, signing the Certificate of Inheritance to the stage of registering inheritance at the Land Office. ${ }^{5}$

Inheritance registration requirements at the local BPN office:

1) Fill out the application form and signed by the applicant.

2) Power of Attorney for registration to the Land Office if the registration is carried out by PPAT.

\begin{tabular}{llllllll}
\hline AKTA: & Vol. & 6, & No. & 4, & $719-726$. & Retrieved & from
\end{tabular}

http://jurnal.unissula.ac.id/index.php/akta/article/view/7668

2 Ibid.

${ }^{3}$ Soekanto, Soejono. (1986). Pengantar Penelitian Hukum. Jakarta: UI Pres, p. 51.

${ }^{4}$ Wahyuni, \& Ma'ruf, Umar. (2020). The function of the Notary / PPAT In filing process Acquisition of Land Rights To Interests Investment in Regional Autonomy Era Based on Act No. 25 of 2007 concerning Foreign Investment. JURNAL AKTA: Vol.7, No. 2, 189-194. Retrieved from http://jurnal.unissula.ac.id/index.php/akta/article/view/7965

${ }^{5}$ Interview with PPAT Heppy Bandaranaike, SH, MKn on February 28, 2017 
3) Photocopy of identity of the applicant/heirs (KTP, KK) and legalized power of attorney if empowered, which has been matched with the original by the counter clerk.

4) Original certificate that has been plotted.

5) Certificate of Death and Certificate of Inheritance which has been legalized by the competent authority.

6) A legalized copy of the last year's PBB SPPT, which has been matched with the original by the counter clerk.

7) SPPD BPHTB that has been verified by DPPKAD.

8) Land Value Zone.

The registration process for the inheritance downstream above until PNBP is paid to the bank usually only takes less than one day. It's just that the new certificate will come out after the next five days.

b. Guarantee Engagement Stage

This guarantee binding is carried out by PPAT based on an order given by the bank. The Collateral Engagement process by PPAT is carried out with the following conditions:

1) Because the guarantee or land certificate is still in process at the Land Office, the PPAT binds the credit guarantee that is still in the process of inheriting using a power of attorney to impose a mortgage (SKMHT) ${ }^{6}$.

2) Photocopy of KTP and KK of all heirs

3) Certificate of Death and Certificate of Inheritance.

4) Photocopy of guarantee or Land Certificate which is in the process of Derivating Inheritance at the Land Office.

After the guarantee agreement requirements are complete, then all heirs will appear to PPAT for the signing of the SKMHT Deed, witnessed by two witnesses from the relevant PPAT employees and also witnessed by the Bank Officials who will disburse the credit.

\section{c. Mortgage Installation Stage}

This stage is carried out after the Inheritance Certificate has been completed at the Land Office. Based on the SKMHT deed that has been signed by all parties, the Deed of Granting Mortgage can be implemented, the things that need to be prepared for the installation of Mortgage Rights in the Land office are as follows:

1) Certificate Check.

2) Preparation of Deed of Granting Mortgage Rights (APHT) based on SKMHT that has been signed by all parties, only the Bank Officials sign the APHT deed,

${ }^{6}$ Interview with PPAT H. Fathoerrahman Ridho, SH on February 27, 2017 
because based on SKMHT all parties, in this case the heirs, have authorized the signing of the deed. ${ }^{7}$

3) Photocopy of KTP and KK of all parties.

4) Photocopy of SPPT PBB.

5) Photocopy of Bank Credit Agreement Letter.

6) Power of Attorney from the Bank Official to PPAT registering with the Land Office . $^{8}$

7) Application Letter from Bank Officials to register for Installation of Mortgage Rights.

8) Introduction to PPAT for registering the APHT deed to the Land Office.

After all the requirements are complete, then the application for installation of mortgage rights is registered at the Land Office. The process of installing Mortgage Rights at the Land Office after the files have been paid, will be after 7 working days, the products that will be issued by the Land Office as a legal consequence of the Registration of Mortgage Rights are the issuance of a Certificate of Mortgage in the name of the creditor or the bank that registered the Mortgage Installation?.

Mortgage certificate is proof that a person has collateral rights imposed on land rights owned by the guarantor (usually the debtor), which gives priority to the holder of the Mortgage Rights over other creditors. ${ }^{10}$

\subsection{Problems of the Role of Land Deed Making Officials in the Installation of Mortgage with the Name of a Certificate of Ownership that Has Died, which is carried out by the Process of Inheritance to Justice-Based Inheritors}

Problems usually arise in determining who is entitled to be called an heir, the determination of heirs can be based on a certificate of inheritance made by the head of the village and the sub-district head, but the statement of inheritance is made without any research so it is not certain, how many heirs an heir. For example, if an heir has more than one wife, the wife can make her own Inheritance Information. This condition results in frequent inheritance disputes because of the overlapping Inheritance Information. ${ }^{11}$

\footnotetext{
${ }^{7}$ Interview with PPAT Heppy Bandaranaike, SH, MKn, on February 28, 2017

${ }^{8}$ Winarti, \& Ngadino. (2019). Review Of Juridical Registration Implementation And Transfer Of Land Or Building With Deed Land Sale In The Office Of The Samarinda City. JURNAL AKTA: Vol. 6, No. 4, 711-718. Retrieved from http://jurnal.unissula.ac.id/index.php/akta/article/view/7595 ${ }^{9}$ Alam, Bahrul., \& Khisni, Akhmad. (2020). Legal Protection of Holders of Land Loss Data In The City Land Office of Kendari. JURNAL AKTA: Vol.7, No. 2, 159-164. Retrieved from http://jurnal.unissula.ac.id/index.php/akta/article/view/7963

${ }^{10}$ www.hukumonline.com, accessed on March 2020

${ }^{11}$ Ibid.
} 
In the case of the Inheritance Process to be used as a credit guarantee at the Bank, usually the problem that arises is the objection of one of the heirs to sign the documents relating to the Inheritance process and the signing of the Credit Guarantee binding at the Bank, this happens because one of the heirs feels that he is not apply for credit at the bank, only siblings apply for credit at the bank, but because the guarantee is still the name of the parent and there is no distribution of inheritance, automatically all heirs must sign documents for the process of inheritance and collateral binding at the bank.

\subsection{How to overcome the problem of the role of land deed-making officials in the installation of mortgage rights with the name of a certificate of ownership that has passed away, which is carried out by the process of inheriting inheritance to justice-based heirs}

In this case, PPAT must be able to provide solutions or solutions for the parties so that each is still legally protected and gets justice. The solutions that can be given to the parties, in this case the heirs, in order to get justice and legal certainty are:

a. Providing counseling about the law to the heirs about the importance of safeguarding shared assets, so that each of them realizes and lives up to their rights and obligations as a family.

b. The process of installing the mortgage has been regulated in the UUHT, so we must comply with these rules. In the case of the installation of a mortgage with the name of the Property Certificate who has passed away, the heirs must also comply with the existing regulations.

If all the heirs support each other's success in advancing their business, the process of applying for a Bank Credit by Installing Mortgage with the Name of a Certificate of Ownership who has passed away can be carried out fairly without anyone feeling aggrieved.

\section{CLOSING}

The role of the official who makes land deeds in installing a mortgage with the name of a certificate of ownership who has passed away must go through the stage of inheritance. Registration of inheritance at the Land Office must be completed by the heirs, these conditions include: Preparation of Inheritance Certificate, Certificate of Inheritance is a letter made by/in front of an authorized official, which explains who the heirs of a person have passed away. Based on the Inheritance Information, the heirs can get their rights, especially the inheritance, By requesting the process of inheriting inheritance at the Land Office, automatically all heirs will become holders of the Right to Ownership Certificate and The role of the Land Deed Making Official in conjunction with the Stages of the Inheritance Process, which is to carry out the Collateral Binding Process at the bank where, the Inheritor signs the Deed of Power of 
Attorney to impose Mortgage Rights, which later when the inheritance is completed, based on the Deed of Power of Attorney to impose the mortgage can directly increased for the implementation of the making of the deed of granting mortgage rights.

\section{References}

Journals:

Alam, Bahrul., \& Khisni, Akhmad. (2020). Legal Protection of Holders of Land Loss Data In The City Land Office of Kendari. JURNAL AKTA: Vol.7, No. 2, 159-164. Retrieved from http://jurnal.unissula.ac.id/index.php/akta/article/view/7963

Chusna, Amalia., \& Hafidz, Jawade. (2019). The Role of the Notary in the Credit Agreement with Mortgage Guarantee (Case Study in the Bank Tabungan Negara (Persero) Tbk). JURNAL AKTA: Vol. 6, No. 4, 719-726. Retrieved from http://jurnal.unissula.ac.id/index.php/akta/article/view/7668

Wahyuni, \& Ma'ruf, Umar. (2020). The function of the Notary / PPAT In filing process Acquisition of Land Rights To Interests Investment in Regional Autonomy Era Based on Act No. 25 of 2007 concerning Foreign Investment. JURNAL AKTA: Vol.7, No. 2, 189-194. Retrieved from http://jurnal.unissula.ac.id/index.php/akta/article/view/7965

Winarti, \& Ngadino. (2019). Review Of Juridical Registration Implementation And Transfer Of Land Or Building With Deed Land Sale In The Office Of The Samarinda City. JURNAL AKTA: Vol. 6, No. 4, 711-718. Retrieved from http://jurnal.unissula.ac.id/index.php/akta/article/view/7595

Book:

Soekanto, Soejono. (1986). Pengantar Penelitian Hukum. Jakarta: UI Pres

Interviews:

Interview with PPAT H. Fathoerrahman Ridho, SH on February 27, 2017

Interview with PPAT Heppy Bandaranaike, SH, MKn on February 28, 2017

Interview with PPAT Heppy Bandaranaike, SH, MKn, on February 28, 2017

Internet:

www.hukumonline.com, accessed on March 2020 